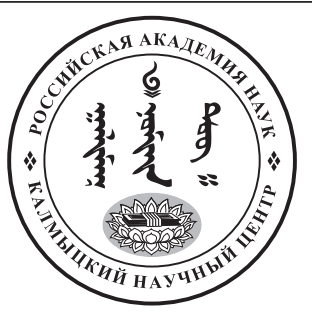

Published in the Russian Federation

Oriental Studies (Previous Name: Bulletin of the Kalmyk Institute

for Humanities of the Russian Academy of Sciences)

Has been issued as a journal since 2008

ISSN: 2619-0990; E-ISSN: 2619-1008

Vol. 13, Is. 4, pp. 876-889, 2020

DOI: $10.22162 / 2619-0990-2020-50-4-876-889$

Journal homepage: https://kigiran.elpub.ru

УДК 94(47).065-066

DOI: $10.22162 / 2619-0990-2020-50-4-876-889$

\title{
Искупленный дважды: толмач Ставропольского войска Афанасий Шорин (опыт реконструкции нетипичной биографии крещеного калмыка второй трети XVIII в.)
}

\author{
Андрей Сергеевич Ряжев
}

${ }^{1}$ Калмыцкий научный центр РАН (8, ул. И. К. Илишкина, 358000 Элиста, Российская Федерация)

кандидат исторических наук, ведущий научный сотрудник

iD 0000-0002-2626-6953. E-mail: ryazhevas@kigiran.com

(C) КалмНЦ РАН, 2020
(C) Ряжев А. С., 2020

Аннотация. Введение. Статья посвящена биографической реконструкции. Впервые в историографии на примере жизни персоналии, в качестве которой выступает толмач Афанасий Иванович Шорин, изучено место крещёной калмыцкой знати в политике Российской империи раннего Нового времени. В работе прослежено становление общения российской власти со степной элитой указанного периода, выявлены важные детали подобного процесса. Цель исследования - воссоздание документальной биографии героя в политико-дипломатическом контексте, сформировавшемся в данную эпоху на степных юго-восточных окраинах государства и прилегающих территориях. Материаль и методы. Исследование основано на материале документов российских центральных и местных учреждений, отразивших этапы биографии представителя социальной верхушки Ставропольского калмыцкого войска (с 1745 г. - корпуса), расквартированного близ крепости Ставрополь-на-Волге. Научный инструментарий работы охватил методы источниковедения и археографии, позволившие провести систематический анализ источников и выявить их связи, отражающие перипетии судьбы персоналии. Результатыл. Историографический раздел текста обозначил важность проблематики истории этноконфессиональных групп, разрешаемой на материалах реконструируемой биографии. В содержательной части присутствует изложение этапов жизни индивида. Наибольшее место уделено фиксации следующих биографических вех: социальный статус, перспективы военной карьеры, попытки к бегству и отказ от строевой службы, двукратное прощение этих провинностей российскими инстанциями - дань заслугам предков, зачисление в Коллегию Иностранных дел, гражданская служба в Ставрополе-на-Волге, выполнение в конце 1750-х гг. важной политической миссии. Выявлено, как и почему жизненная траектория, весьма необычная для человека подобного круга и происхождения, отразила процессы взаимодействия российской 
стороны с кочевниками степных юго-восточных окраин и сопредельных территорий. Также подчеркнута значимость ойратского фактора для государства до и после падения Джунгарии и упразднения Калмыцкого ханства. Параллельно дана характеристика настроений ставропольского правящего звена, подчеркнута его неудовлетворенность своим положением к концу 1760-х гг. из-за ограничений, продиктованных сословной политикой властей. В статье проведена мысль, что именно внутреннее недовольство толкнуло высшую страту войска на участие в Пугачевщине. Заключение. В итоге автор констатирует, что крещеная калмыцкая аристократия и близкие к ней слои калмыцкого общества сыграли заметную роль во внешней и вероисповедной политике при Елизавете Петровне и в начале царствования Екатерины II, чем и объяснялось повышенное внимание к ним сверху. Но по истечении избранного хронологического периода их востребованность в рамках пограничного военно-политического уклада, соответственно, их субъектность оказалась во многом исчерпанной.

Ключевые слова: Российская империя, раннее Новое время, Елизавета Петровна, Екатерина II, толмач Афанасий Иванович Шорин, степные юго-восточные окраины, этноконфессиональные группы, Ставропольское калмыцкое войско (корпус), внешняя политика, вероисповедная политика, сословная политика, кочевники

Благодарность. Исследование проведено в рамках государственной субсидии - проект «Комплексное исследование процессов общественно-политического и культурного развития народов Юга России» (номер госрегистрации: АААА-А19-119011490038-5).

Для цитирования: Ряжев А. С. Искупленный дважды: толмач Ставропольского войска Афанасий Шорин (опыт реконструкции нетипичной биографии крещеного калмыка второй трети XVIII в.) // Oriental Studies. 2020. T. 13. № 4. C. 876-889. DOI: 10.22162/2619-0990-2020-50-4876-889

UDC 94(47).065-066

DOI: $10.22162 / 2619-0990-2020-50-4-876-889$

\title{
He Who Was Redeemed Twice: Afanasy Shorin, a Stavropol Host Interpreter. Reconstructing a Non-Typical Biography of the Kalmyk Christian, Second Third of the $18^{\text {th }}$ century
}

\author{
Andrey S. Ryazhev ${ }^{1}$
}

${ }^{1}$ Kalmyk Scientific Center of the RAS (8, Ilishkin St., Elista 358000, Russian Federation)

Cand. Sc. (History), Leading Research Associate

iD 0000-0002-2626-6953. E-mail: ryazhevas@kigiran.com

\author{
(C) KalmSC RAS, 2020 \\ (C) Ryazhev A. S., 2020
}

\begin{abstract}
Introduction. Religious policies of the Russian Empire in early modern history is a topical issue of historiography. An important (though poorly researched) aspect of this question is the role of Kalmyk Christian elites. Being part of the diverse ethnoreligious cluster, the latter served as a conductor of Russia's influence on subject nomadic communities (Oirats, Turkic tribes) during the period under consideration across southeastern steppe peripheries and adjacent territories. The Stavropol Kalmyk host established in 1737, quartered next to the fortress of Stavropol-on-Volga, and since 1745 referred to as Stavropol Corps of Kalmyk Christians was one of such groups.Goals. The study seeks to reconstruct the biography of Afanasy Shorin, an interpreter socially representing army elites. His life journey may be instrumental in tracing the shaping (and details) of communication patterns between Russian authorities and steppe leaders during the mentioned period. Materials and Methods. The study analyses rich source materials from Russia's central and local institutions that reflect certain phases of Afanasy Shorin's biography. The research tools include those of source
\end{abstract}


criticism and archaeography which provided a systematic insight into the documents. Special attention is paid to the collected indirect testimonies that would clarify separate aspects of the person's life. Results.The biography reconstructed from the documents contains a number of milestones, such as birthright privileges, military career prospects, escape attempts and refusal of active service, two discharges from any liability for the offences by the Russian authorities as a tribute to the social status and merits of ancestors, admission to the Collegium of Foreign Affairs, civil service in Stavropol-onVolga, and an important political mission in 1757-1758. The article identifies how and why the life trajectory unusual for a representative of such background and status - a school teacher, interpreter but not a military officer - reflected the processes of interaction between Russia proper and steppe nomads. It also underlines the importance of the Oirat factor for the state before and after the fall of Dzungaria. In the meantime, the text describes sentiments of the Stavropol host leadership and emphasizes the dissatisfaction with restrictions to have resulted from social class policies of Russian authorities by the late 1760s. The article contains the idea that it was the discontent with his position, which was fully characteristic of many including Afanasy Shorin, that pushed the highest authorities of the host to participate in the Yemelyan Pugachev's Rebellion. As a possible prospect, the departure was suggested, by the example of the Kalmyks of Ubashi Khan, who departed to China in 1771. The article proves first to reveal the mechanism of how service conditions, kinship and confessional contacts influenced the inclusion of Kalmyk Christian elites into the border Russian military-andpolitical system. The text gives arguments that essentially contradict the trend (previously expressed in historiography) to consider the anti-serfdom protest as the only reason why Stavropol Kalmyks supported Pugachev's Rebellion. Conclusions. The paper concludes the Kalmyk Christian nobility and related elites of the Kalmyk community played a significant role in foreign and religious policies under Elizaveta Petrovna and in the early years of Catherine the Great's reign, which explains the increased attention of the government towards them. However, their relevance within the established border system and, consequently, their positions were largely exhausted in the $1770 \mathrm{~s}$. This was also facilitated by the decline in the importance of the Oirats, and the rise of the Turkic direction in Russia's foreign policy in the south and southeast.

Keywords: Russian Empire, early modern history, Elizaveta Petrovna, Catherine the Great, interpreter Afanasy Shorin, southeastern steppe borders, ethnoreligious groups, Stavropol Kalmyk Host (Corps), foreign policy, religious policy, estate policy, nomads

Acknowledgements. The reported study was funded by government subsidy — project name 'Socio-Political and Cultural Development of South Russia's Peoples: a Comprehensive Research of Respective Processes' (state reg. no. AAAA-A19-119011490038-5).

For citation: Ryazhev A. S. He Who Was Redeemed Twice: Afanasy Shorin, a Stavropol Host Interpreter. Reconstructing a Non-Typical Biography of the Kalmyk Christian, Second Third of the $18^{\text {th }}$ century. Oriental Studies. 2020. Vol. 13(4): 876-889. (In Russ.). DOI: 10.22162/2619-09902020-50-4-876-889

\section{है}

\section{Введение}

На протяжении последних двух десятков лет актуальным направлением изучения Российской империи в Новое время оставалась вероисповедная политика. Важный аспект подобной политики - создание государством со времен Северной войны новых служилых сословий, преимущественно из нерусского населения, их интеграция в рамках военно-политического уклада на южных и юго-восточных окраинах страны. Процессы складывались не гладко, более того, в ряде случаев весьма болезненно, что имело влияние на коллективные и индивидуальные биографии проводников и агентов имперского строительства. Индивидуализация в данной связи представляется обоснованной именно при подходах к элитным группам в этноконфессиональной среде, по определению малочисленным. К таковым относится и служилая верхушка Ставропольского калмыцкого войска, возникшего в 1737 г. на Средней Волге и включенного в пограничную систему западной 
части Оренбургской линии. Инициатором создания войска выступил Баксадай Доржи, внук Аюки-хана, перешедший в православие в 1724 г. и получивший новые имя и титул - князь П. П. Тайшин. В центре исследования - судьба Афанасия Ивановича Шорина, крещеного калмыка, выходца из войска, испытавшего превратности судьбы и закончившего свои дни толмачом при Ставропольской канцелярии и учителем детей знати в войсковой школе.

\section{Материалы и методы}

Главный источник, раскрывающий планиду А. И. Шорина, - бумаги Коллегии Иностранных дел, походной канцелярии оренбургского губернатора И. И. Неплюева, а также губернатора и его подчиненных - должностных лиц ведомства Оренбургской линии (коменданта Ставрополя-на-Волге полковника Б. Останкова, бригадира А. И. Тевкелева). В них содержится информация о жизни и службе нашего героя в Ставропольской и Красноуфимской крепостях Оренбургской губернии, Москве, Санкт-Петербурге и снова Ставрополе-на-Волге [Волжские 2011: 191-193, 195-198, 213-216]. Здесь и документы, объясняющие нравы и условия службы ставропольского войскового командного состава в целом [Волжские 2011: 51, 52, 69-72, 109-127, 177, 179-186, 211, 212, 220-224, 241-251, 255-259]. Они дают представление об отношениях последнего с властями, раскрывают уровень его социальных привилегий, черты менталитета, степень участия в политике государства на подступах к Великой степи, и потому значение названных материалов трудно переоценить.

Инструментарий работы охватил методы анализа документов и обобщения полученных данных. Анализ носил систематический характер для выявления обстоятельств жизни и службы, в особенности отраженных косвенно. Подобный анализ позволил, прежде всего, воссоздать основные вехи биографии А. И. Шорина - одного из влиятельных лиц Ставропольского войска, завершившего служебную карьеру столь необычно для людей его круга. Кроме того, предлагаемый подход дал возможность дополнить историю российских контактов с ойратской (калмыцкой, джунгарской) аристократией ценными деталями, вскрываю- щими специфику коммуникации с кочевниками и сохраненными именно из-за участия А. И. Шорина.

Выходец из служилого сословия: воссозданное жизнеописание

Биография служилого человека всегда имеет политическую основу. Жизненный путь А. И. Шорина, несмотря на нестандартность, не явился исключением. Обращение к политическим процессам, в которых задействовались крещеные привилегированные калмыки, делает нужным очерк соответствующей литературы. Посему далее три главных пункта - историографический сюжет отношений России со степью, биография персоналии и характеристика обозначенного ею политико-дипломатического контекста.

\section{Индивид и его эпоха: очерк историо- графии}

В течение истекших двадцати лет в литературе по общественно-политической истории России в Новое время доминирует имперская тематика. За это время сложилось особое направление «новой имперской истории», применительно к которому среди ученых обрисовались, с одной стороны, явная поддержка, с другой, неприкрытый скепсис. В границах данного направления сформулирован региональный подход, сопровождавшийся специфическим пониманием локального. Он, в частности, позволил вывести на передний план окраинные местные элиты и элитные группы - объекты и вместе с тем субъекты имперской политики [Миллер 2006: 14-49]. В силу наличествующей историографической традиции поиск во многом вращался вокруг мусульман служилых сословий, духовенства, шире носителей исламской учености и затрагивал более поздний период [Frank 2001; Werth 2002; Арапов 2008]. Похожие вопросы ставились в отношении неправославного дворянства и духовенства западных губерний. С учетом территориальных приращений России в XVIII в. в литературе представлена стройная картина взаимодействия монархии с привилегированными статусными группами имперских окраин [Ибнеева 2009].

В наши дни в науке налицо понимание геополитической необходимости движения России на юг и восток в Новое время, соответственно, трактовка азиатских про- 
странств как стратегического «балкона» имперского развития, выступивших в этом качестве в годы Северной войны и позже. В восточной политике России этого времени отмечен принципиальный характер джунгарского фактора, выведена констатация важности для государства связей с калмыцкими ханами и аристократией. Подчеркивается, что возведение Оренбургской оборонительной линии - российского аналога Великой стены — в видах безопасности границ на огромном расстоянии от Каспия до Сибири сделало это важное значение в 1730-1750-е гг. еще более настоятельным [LeDonne 2008: 21-32].

Отсюда же берет начало осмысление роли традиционной калмыцкой аристократии в южной политике России. Оно, прежде всего, предпринималось в рамках концепции аккультурации и позволило отметить смену поколений командного состава ставропольцев в последней трети XVIII - начале XIX в. [Джунджузов, Любичанковский 2018: 972-976; Goryaev, Lidzhiev, Avliev 2019: 1138-1140; Джунджузов 2020: 82-86].

Большой интерес вызывает трактовка мотивов принятия православия калмыцкой кочевой знатью с позиции теории элит. При этом показано, что процесс перемены исповедания не был широким: христианство к концу XVIII в. приняла лишь десятая часть ее высшего слоя [Дорджиева 2008]. Для дальнейшего прогресса исследований нужно изучить, помимо калмыцких нойонов (владельцев), более широкий контингент степной верхушки. Следует принять во внимание не только ее личные мотивы, определившие религиозные предпочтения, но и комплексное воздействие имперского «хронотопа» на стыке кочевых и оседлых обществ, влиявшее на выбор религии.

С 2000-х гг. специалистов привлекало и сочетание разнонаправленных тенденций во взаимодействии государства со степью имперского интегризма и защиты властями автономии степных сообществ. Также предметом углубленного анализа выступала роль старых и новых элитных групп как субъектов российских действий в степных делах, при этом учитывалось влияние религиозного фактора [Абдилдабекова 2010; Werth 2013: 126-130; Торопицын 2015; Третьякова, Мыслицкая, 2015; Вовк, Шебалин 2016: 194, 195; Васильев 2017; Ходарков- ский 2019: 198-255]. Главным условием дальнейшего развития тематики становится ее историографическое освоение, по уровню сегодня уступающее содержательному [Тебаев 2009; Петухов 2014].

C позиции субъектности калмыцкой элиты весьма интересно изучение участия Ставропольского калмыцкого войска в восстании Е. И. Пугачева. Его давнишняя и прямолинейная - сквозь призму классовой борьбы - трактовка [Беликов 1971; Беликов 1978] ныне существенно скорректирована [Джунджузов 2013; Смирнов 2007: 163-165]. Имеет смысл подчеркнуть: Ставропольское калмыцкое войско — «маленькую Калмыкию» на Средней Волге, связанную многими нитями с Калмыцкой степью, нельзя отрывать от нее, несмотря на вероисповедное различие. Уход калмыков Убаши-хана в Китай в 1771 г. и упразднение Калмыцкого ханства Екатериной II вызвали резонанс в среде войсковой верхушки. Поэтому подключение ставропольского воинства к Пугачевщине выглядит попыткой заправил войска организовать своего рода анабасис - откочевку по примеру соплеменников ближе к исторической родине, хотя попыткой весьма и весьма авантюрной. Таковы в целом подходы научной литературы к проблематике крещеной калмыцкой элиты и ее места в политике России раннего Нового времени.

\section{Портрет героя: в свете выявленных документов}

Материалы источников, ложащиеся в основу воссоздаваемого жизнеописания ставропольского толмача на фоне эпохи, вполне коррелируют с историографическими основаниями. Основные вехи жизнеописания таковы: происхождение, вступление в сознательный возраст и коренной поворот судьбы, заключительные жизненные перипетии.

Касательно происхождения и социальных перспектив нашего героя. Он был представителем высшего ставропольского слоя, сформировавшегося к середине 1740-х гг. из двух близких по статусу групп. Первую составили люди князя П. П. Тайшина, принявшие православие вместе с ним. Вторая охватила родственников князя и его вдовы, княгини А. А. Тайшиной, откочевывавших из Калмыцкой степи на Дон, затем крестив- 
шихся в Ставрополе и вместе с крещением получавших княжеские титулы.

Сподвижники П. П. Тайшина, сплотившиеся вокруг А. А. Тайшиной после создания войска, названы первым комендантом Ставрополя полковником А. И. Змеёвым в представлении начальникам Оренбургской и Башкирской комиссий В. Н. Татищеву и Л. Я. Соймонову от 18 декабря 1737 г. В документе значится: «...а ныне при оной княгине имеется зайсангов... Иван Шоро, Петр Менко, Кирило Шарап, Матвей Бату Менко, Иван Чидор.., Григорей Дайши Замсо, Семен Тюря, Иван Мангут, Афанасей Тукан, Григорей Балдан, Сергей Ясул Гецуль, Иван Амур, Василей Даадан, Федор Котема, Андрей Дабрицын, Костентин Ходжин, Андрей Ламаджан. Да... для всяких... от нея в... улусы посылок определить... Нестера Цодаша, Степана Кюрю...» [Волжские 2011: 70]. Иван Шоро, отец Афанасия, упомянут, таким образом, среди доверенных людей четы Тайшиных самым первым.

Сын вписался в эту страту по праву рождения, значит, беспрепятственно. В реестре Оренбургской губернской канцелярии от 24 сентября 1744 г. о раздаче личного имущества покойной княгини А. А. Тайшиной представлен персональный состав ставропольского «высшего общества» - в первой группе получателей здесь перечислены наиболее влиятельные люди, их жены и дети. Выдача вещей производилась, в частности, «Шориной жене с сыном» — им достались «коляска городовая 3 дышлом и старыми шорами, подушка круглая покрыта алым сукном, книга простая в позолоченой оправе, две чарки серебреных, две лошки серебреных» [Волжские 2011: 111]. По штату Ставропольского войска «бывшаго (к тому времени уже покойного. - $A$. $P$.) полковника Шоры сыну Афанасью» шел особый оклад - 50 руб. в год. А. И. Шорина, на тот момент никаких чинов в войске не имевшего, выдвинули на одно из высших штатных мест. Перед ним значились аристократы и старшие командиры, после него - все прочие вакансии строевых офицеров и номенклатуры войска: ротмистров, «харунжих», «ясаулов», урядника, вестового («розсыльщика») и православного духовенства и причта [Волжские 2011: 119].

Дата рождения А. И. Шорина не известна, но понятно, что человеком тогда он был молодым. Перед ним была открытая слу- жебная перспектива, и документы говорят недвусмысленно о том, как она сложилась бы. Известен случай 1768 г. о производстве в офицеры шестнадцатилетнего Ивана Торгоутского. Юноша войском не аттестовывался, звание шло не в очередь, но его мать Веру Андрееву, даму отнюдь не из простонародья - вдову крещеного владельца полковника Павла Торгоутского и бывшую ханшу (в свое время она была замужем за ханом Церен-Дондуком) названные «мелочи» не останавливали. Она находила, что офицерский чин полагается сыну по праву рождения и «за службу отца ево, а моего покойного мужа». Ставропольская канцелярия, вступившая в этой связи в переписку с оренбургским губернатором А. А. Путятиным, в справке по делу признала: порядок, к которому апеллировала Вера Андреева, имеет давние корни, «ибо де напред сего ис таких же владельческих детей.., не имея ж прежде никаких чинов, произведены... люди также еще молодые...» [Волжские 2011: 242, 243]. В подобный порядок изначально встроили и А. И. Шорина.

Следующая ступень биографии - начало жизни в свете очерченной перспективы. Она явно не прельстила героя: Афанасий бежал в Калмыцкую степь. Тем самым он обозначил радикальный отход от служебной траектории, типичной для человека его круга. Побег не был одиночным: к А. И. Шорину присоединился зайсанг Ф. Котема, как и И. Шоро, человек князя П. П. Тайшина из списка полковника А. И. Змеёва 1737 г. Замысел не удался - последовала поимка. Беглецы, в том числе А. И. Шорин, получили прощение как люди видные, однако были направлены в ссылку, откуда вновь бежали.

События изложены в указе Иностранной коллегии оренбургскому губернатору И. И. Неплюеву от 1 сентября 1752 г. Здесь читаем: в январе «из живущих в Ставрополе крещеных калмык Федор Котема и Афонасей Шорин с товарыщи за намерение их к побегу оттуда отлучены и отосланы были в Красноуфинскую крепость (ныне г. Красноуфимск Свердловской области, тогда в Уфимской провинции Оренбургской губернии - A. P.), однако же и оттуда они бегали и увели было с собою несколько обывательских лошадей, но посланною из той крепости партиею переловлены и за то... высечены плетьми» [Волжские 2011: 192]. 
Побеги членов двух семейств ставропольских начальников «первого часа» говорят о явной неудовлетворенности и нежелании нести службу в Ставрополе. На основании документов можно констатировать, что упадочническое настроение среди части зайсангов могло быть вызвано сложившейся «олигархической» системой управления войском, но прорывалось вовне по разным причинам - местнические счеты, честолюбие, нехватка средств на жизнь, получаемых на службе, и бедность служилых калмыков [Волжские 2011: 114-121, 189-191, 194-196, 222, 248, 255].

В итоге тем, кому изначально не было места в узком составе высшей страты войска, или выпавшим из него, оставалось лишь покинуть Ставрополь (переводиться по службе, бежать) или же, признавая свою неудачливость, пробавляться ремеслом и торговлей. А. И. Шорин рос, зная о подобных мотивах разрыва со здешней военной карьерой, но ни один из них его не коснулся - у него выискался свой.

Свой и, опять-таки, если брать его ровесников и социальную среду, нетипичный: он не хотел нести строевую командную службу и категорически возражал против своего назначения на офицерские вакансии. В апреле 1756 г., после длительного отсутствия вновь прибыв в Ставрополь-на-Волге, он заявил об этом определенно, и канцелярия наконец-то смогла доложить губернатору И. И. Неплюеву: «в харунжие он, Шорин, не желает...» [Волжские 2011: 214].

Причина побегов скрывалась именно здесь: сын одного из самых стойких воинов П. П. Тайшина наотрез отказывался садиться в седло и брать в руки оружие. Посему его последующая жизнь - это жизнь штатского служащего, что для того времени и для калмыка нерядового происхождения есть казус редчайший.

Заключительные жизненные перипетии героя также ординарностью не отличались. В целом после побега из Красноуфимской крепости они сложились для А. И. Шорина неплохо. Важную роль сыграли два обстоятельства. Во-первых, его пожизненной «золотой акцией» были происхождение и репутация родственников перед российскими властями. Во-вторых, на благо сказалось участие губернатора И. И. Неплюева - доброго гения ставропольских калмыков.
Именно статус предков А. И. Шорина выступал в цитированном указе Коллегии Иностранных дел И. И. Неплюеву от 1 сентября 1752 г. аргументом при новой отмене суровой кары (плети по тем временам не в счет) и прощении после двух побегов. «А по справке в Коллегии... с делами прошедших лет, — говорится в указе, - из вышеписанных бегавших калмык... Афонасей Шорин сын бывшаго полковника крещеных калмык Ивана Шоры, которой во всем калмыцком народе знатной и богатой зайсанг был...». Не был забыт и знатный дед А. И. Шорина, от которого «К здешней стороне (российским властям. - $A$. Р.) было не без службы». «Того ради за благо разсуждается, заключал указ, - вышеписанного... Афонасья Шорина... взять сюда и определить в Коллегию», ибо он владел двумя языками и мог быть и «калмыцкого языка толмачем.., и по руски читать и писать умеет...» [Волжские 2011: 192, 193].

И. И. Неплюев отдал нужное повеление: об этом известно из указа его походной канцелярии в Оренбургскую канцелярию от 2 сентября 1752 г. Рапорт бригадира И. А. Тевлелева на имя И. И. Неплюева от 8 сентября 1752 г. гласит, что распоряжение об отъезде А. И. Шорина «в тое Коллегию... для определения в толмачи... оттоль из Красноуфинска, дав ему собраться со всем тем, что при нем есть...», ушло на место, и посылка беглеца в Москву состоялась [Волжские 2011: 195, 196, 198].

В должности толмача Московской конторы Коллегии Иностранных дел А. И. Шорин провел несколько лет, но в итоге пришелся не ко двору. Из указа походной канцелярии И. И. Неплюева в Оренбургскую губернскую канцелярию от 16 мая 1756 г. известно: «умершаго калмыцкого полковника Шоры сына Афанасья Шорина... велено Канторе оной Коллегии отправить возвратно в Ставрополь, а тамо ево, Шорина... определить к такому делу, к какому он явится способен» [Волжские 2011: 213].

В апреле 1756 г., как отмечалось, А. И. Шорин прибыл в Ставропольскую канцелярию, которая дала о нем следующий отзыв: «в харунжие... не желает, да по нынешнему ево состоянию и поведению здесь усмотрено, что ему сходне быть при штатских делах, нежели в нерегулярной военной службе, яко он по руски говорить, читать 
и писать да переводы сочинять без нужды (без затруднений. - A. P.) уже умеет, и к тому ж» усвоил уклад учреждений «и во всех обрядах (служебных процедурах. A. P.) не яко калмык, но яко руской человек вид делает» [Волжские 2011: 214].

И. И. Неплюев, весьма ценивший ставропольских калмыков высшего звена, отнесся внимательно и к толмачу. Он предполагал заместить им место учителя в калмыцкой школе, произведя в командиры одного из учителей, «ежели же паче чаяния ис оных... в харунжие никто не похочет, в таком случае ево, Шорина, за неимением ныне особливаго для него места, доколе впредь особливая какая ваканция очистится, употреблять при канцелярии к переводам и толмачеству, и школе уже и сверх их (переводческих обязанностей. - A. P.) 3 жалованьем по тритцети по шести рублев в год, какое он и в Москве получал...» [Волжские 2011: 215, 216]. В дальнейшем А. И. Шорин продолжал служить толмачом при войске и учителем в войсковой школе, где обучались дети калмыцких командиров.

И. И. Неплюев также подключал его к деликатной политической миссии. Летом 1757 г. в Россию вышли остатки джунгар, искавшие после гибели Джунгарского ханства спасения от войск Цинов. Беглецами предводительствовала значительная группа знати, во главе которой стоял нойон Норбо Данжин - двоюродный брат Амурсаны, последнего правителя Джунгарии. И. И. Неплюев стремился привлечь выходцев в Ставрополь, а посему по его приказу к ним и был прикомандирован А. И. Шорин. Он отвез знатным перебежчикам письма коменданта Ставрополя и состоял при них с июля 1757 г. по сентябрь 1758 г., включая известное время пребывания Норбо Данжина в Санкт-Петербурге [Волжские 2011: 223, 231].

Войско пополнилось-таки джунгарами, Норбо Данжин вместе с родственниками принял православие и получил чин полковника войска (но к месту службы не поехал, обладая важными сведениями и будучи затребованным в Коллегию Иностранных дел) - в целом миссия А. И. Шорина имела успех, а он вернулся к своим обязанностям учителя и толмача. Такова биография «штатского зайсанга» - продолжателя двух воинственных калмыцких родов и па- цифиста волею судьбы, дважды искупленного от кнута палача заслугами родни.

Превратности судьбы: политико-дипломатический контекст

Нетипичная биография лишь подчеркивает инвариантный, принципиальный характер отразившихся в ней общественных процессов. Уместно выделить две группы таковых: одни охватывают взаимоотношения государства со степью в целом, другие - эволюцию верхов ставропольского воинства, представляемых А. И. Шориным.

По поводу первой группы. Для государства главенствующая часть калмыцкого воинства Ставрополя имела, помимо сугубо военного, и политический вес. Крещеная верхушка выступала посредником между российскими чиновниками, с одной стороны, и некрещеной знатью, степной и отчасти горской, на юге и юго-востоке России с другой. Работа посреднического политического механизма зафиксирована в известном указе Коллегии Иностранных дел от 1 сентября 1752 г.

Вот в указе родственные связи толмача - его отец, мать, дядя, дед: «калмык называемой Афонасей Шорин сын бывшаго полковника крещеных калмык Ивана Шоры, которой во всем калмыцком народе знатной и богатой зайсанг был, что и сим свидетельствуется, яко брат оного Шоры Дубжур от семи сот до тысячи кибиток своих подданных имел и в 1725 году возжелал было креститься и по представлению губернатора Волынского, а по имянному указу... Петра Великаго... повелено было ему за то определить годоваго жалования денег по пяти сот рублев да хлеба по двести по пятидесяти четвертей, полковника же Шоры жена, а помянутаго Афанасья Шорина мать, дочь калмыцкого зайсанга Гумеджапа, которой как при хане Черен Дондуке был, так и при нынешнем наместнике ханства Дондук Даше находится и в их Зарге обще с другими знатными зайсанги судьею и бывает во всех с ним советах...» [Волжские 2011: 192].

Вот действие родственных отношений в политических видах властей: «...от него ж (Гумеджапа. - A. P.) к здешней стороне было не без службы, а имянно в 1736 году и во время турецкой войны в бытность здесь 
Калмыцкого хана Черен Дондука и крещеного владельца Петра Тайшина посыланы были отсюда для приведения от Астрахани калмыцких войск в Самару к поискам над бунтовавшими башкирцами... Петра Тайшина зайсанг Матвей Гелдей, Петра Толстова крестник, а от хана Черен Дондука вышеписанной Гумеджап, и первой из них, забрав от Астрахани несколько сот крещеных калмык, вместо Самары увел к хану Дондук Омбе, которые там по прежнему обратились в идолопоклонение, а напротив того оной Гумеджап приводил от Астрахани несколько же сот некрещеных калмык, с ханом Дондук Омбою еще тогда несоединившихся, которые над башкирцами и поиски производили...» [Волжские 2011: 192, 193].

И вот финал - смысл посредничества, исповедуемый государством: «...и тако по той причине и по доброжелательству онаго зайсанга Гумеджапа в 1747 году октября от 28 дня полковнику Спицыну указом отсюда рекомендовано с ним, Гумеджапом, сдружиться, и чрез него разведывать о намерениях нынешняго наместника ханства, и понеже таким образом небеспотребно есть, чтоб и впредь онаго Гумеджапа, яко во всем калмыцком народе знатного зайсанга для всяких случаев к здешней стороне ласкать...» [Волжские 2011: 193].

Подобное посредничество становилось и возможным, и весьма действенным, ибо в первые двадцать-тридцать лет связи между Ставропольским войском и Калмыцким ханством не ослабевали, а способы их поддержания оказывались, как следует из источников, различными: выход пленников - уроженцев ханства из степи в Ставрополь, обмен курьерами и посланиями, взаимные гостевые поездки - несмотря на формальные запреты - ставропольских и ханских калмыков [Волжские 2011: 166, $171,183,185,256,257]$.

Посему и рядовые крещеные калмыки, и знать были в курсе степных дел. Этому способствовало и многообразие аспектов во взаимоотношениях властей и степняков (помощь пленникам, династические браки, участие в войнах, подавление народных движений на окраинах), в которых крещеные калмыки обеспечивали коммуникацию сторон, обратную связь российским инстанциям и в итоге - интересы государства.
Порой это происходило непрямым и даже причудливым образом. Эпизод политической борьбы 1736 г. на юго-востоке России, изложенный в упоминавшемся указе Иностранной коллегии от 1 сентября 1752 г. - весьма красноречивое свидетельство на сей счет. В самом деле, в разгар башкирского восстания человек князя П. П. Тайшина, слывшего российской креатурой, крещеный зайсанг Матвей Гелдей, чьим воспреемником был выдающийся петровский дипломат П. А. Толстой, вдруг увел крещеных калмыков, назначенных против башкир, к Дондуку-Омбо, конфликтовавшему тогда с российским начальством, и отрекся от христианства. Между тем тесть Ивана Шоро, другого крещеного зайсанга из окружения того же П. П. Тайшина, некрещеный зайсанг Гумеджап собрал в степи некрещеных калмыков и двинул их против башкир, выполнив повеление свыше. Для российской дипломатии, таким образом, ценность возымела система родства представителей крещеной верхушки в целом и политическая ориентация, возможная благодаря родственным контактам.

Осознавая политическую важность привилегированного слоя ставропольцев, губернатор И. И. Неплюев не уставал напоминать о необходимости корректного поведения чиновников и командиров на местах. Показательна трактовка сановником случая нарушения служебной автономии ставропольцев, имевшего место на марше их отряда во время подавления восстания Батырши в июле 1755 г. Поручик Луцкой, командовавший частью, в которую входили калмыки, подал рапорт на их есаулов «с показанием их против ево ослушностей, непорядков и соблазненнаго бесчинства...» [Волжские 2011: 205]. Но те направили встречный рапорт «в наказании их... якоб безвинно...» [Волжские 2011: 205].

И. И. Неплюев защитил есаулов: «... калмыки... неправы, токмо ему, Луцкому, в такие наказании беспосредственно собою вступать не надлежало, но... по согласию с их... командиром ротмистром Анчуковым.., яко он, Анчуков, для того при них командиром и учрежден...» [Волжские 2011: 205]. В итоге Луцкого отстранили, а его начальник, полковник Роден, получил порицание [Волжские 2011: 205, 206]. 
При подготовке прибытия в Ставрополь новобранцев-джунгар И. И. Неплюев давал назидания коменданту Б. Останкову: «к тем зайсангам и калмыкам доброжелательной вид показывать, и по самой справедливости христианской благосклонным и почтительным к ним быть.., и тако бы Ставропольской корпус в лутчую Высочайших Е. И. В. интересов пользу более умножиться мог» [Волжские 2011: 223].

Подобная основа закладывалась в 1730-е гг.: аналогичные предписания комендант А. И. Змеёв получал в свое время от В. Н. Татищева.

Для ставропольской верхушки 4060-е гг. XVIII в. - это «золотой век», и А. И. Шорин в течение жизни вкушал его плоды, пусть и с переменным успехом. К началу же 1770-х гг. ситуация изменилась к худшему. Причины сдвига налицо. После падения Джунгарии сократилось влияние ойратского фактора в восточной политике России. Переход при Екатерине II к политике веротерпимости, выстраивание прямых связей с влиятельными людьми в тюркской степной среде, ликвидация Калмыцкого ханства после откочевки в цинское подданство части калмыков также снижали значение калмыцкого посредничества в отношениях российских властей со степью. Таковы итоги государственной политики, к которой оказался причастен верхний слой ставропольцев.

Наконец, о второй группе процессов, связанных, как сказано выше, с эволюцией ставропольской верхушки в диалоге с властями. Индивидуальная судьба толмача, олицетворявшего эту верхушку - вполне репрезентативный пример врастания крещеного иноэтничного уроженца в русское общество. Данный процесс фиксировался в документах неоднократно: «определить в Коллегию калмыцкого языка толмачем, который... и по руски читать и писать умеет...», «яко он по руски говорить, читать и писать да переводы сочинять без нужды уже умеет, и к тому ж и во всех обрядах не яко калмык, но яко руской человек вид делает» [Волжские 2011: 193, 214]. И здесь герой был отнюдь не одинок: стоит вспомнить о сыновьях князя Никиты Тайшина братьях Дербетевых (особенно известен младший - депутат Уложенной комиссии
Екатерины II) и князе Павле Торгоутском.

Высшей точкой социальных устремлений ставропольской «олигархии», к которым был причастен и А. И. Шорин, стали претензии на душевладение и равный в этом плане статус с дворянством. Начальники войска проявили на сей счет исключительную солидарность, о чем говорит их обращение в Ставропольскую канцелярию 1768 г. «...Сего октября 10 дня.., - гласит документ, - Ставропольского калмыцкого корпуса войсковый полковник Иван Мартемьянов, судья Василей Делдюш, надзиратель улусов Флор [и] квартермистр Яков Торгоуцкие, харунжей Козма Баглюнов и протчие старшины, владельцы и зайсанги поданным доношением... просят они, старшины, владельцы и зайсанги, позволить им у российских дворян дворовых людей и крестьян покупать и на пожалованных им землях селить сколько кому капитал свой дозволит...» [Волжские 2011: 260, 261].

В доношении командиры, прежде всего, напомнили о своей службе государству: «... на пожалованной им в Ставропольской округе по Волге, по Соку и по Кондурче рекам земле слободами поселены, и употребляются как они, старшины, так и рядовые в нерегулярную службу в разные партии...». Затем они перешли к юридическому обоснованию владения крестьянами, обещанного в свое время В. Н. Татищевым княгине А. А. Тайшиной и затем вошедшего в законы о Ставропольском калмыцком поселении [Волжские 2011: 79, 80, 261]. Давние гарантии, по мнению командиров, ныне обязаны были повлечь продолжение: «...когда им, княгине и зайсангам, обещано пожалование деревень, то, следственно, и покупать их невозбранно...» [Волжские 2011: 261].

Подняли офицеры и установления 1740-х гг., формально отменявшие социальную зависимость служилого калмыцкого простонародья. В доношении по этому поводу сказано так: «до восприятия святого крещения находились они в Калмыцкой волжской орде с имеющимися при них подданными улусными калмыками и, вышед из оной орды со оными улусными своими калмыками в подданство при блаженной памяти государыне императрице Анне Иоанновне с покойною княгинею Анною Тай- 
шиною в город Ставрополь, где святое крещение приняли... и потому с восприятием христианския веры означенные их улусные калмыки, яко уже служилые люди, всеми услугами и податьми, каковые, будучи в орде, исполняли, от них, владельцов и зайсангов, уже отрешены...» [Волжские 2011: 260]. Излишне напоминать, что пресловутых «улусных калмыков» никто от повинностей в пользу господствующей группы отнюдь не «отрешал», но правовая норма, презиравшаяся ранее, стала удобным поводом апелляции к властям теперь.

Социальный же мотив душевладения, обозначенный в документе, был в духе дискурса крепостнической эпохи, признанного в том числе и указом Сената от 15 февраля 1745 г. «О правилах содержания и управления Ставропольской крепостью и поселенных при ней калмыках» - основополагающим указом о ставропольских калмыках: «господам» нельзя без «рабов», «дабы чрез то лучшия и заслуженных людей фамилии в презрение и уничтожение не приходили» [ПС3 1830: 314].

Об этом заявляли и ставропольские зайсанги: «...а по природе их, владельцов и зайсангов, для домашних услуг бес таковых людей, которые черную работу исправляли, обойтись не могут, и хотя де поныне с нуждою и справляются наймом ис крещеных же калмык, но за немалую плату з большим себе убытком, а притом и без пользы, ибо де они, калмыки, такой работы исправлять и земледелия производить как российские крестьяне еще необыклые...». Посему крестьяне и понадобились, «которых, кроме покупки у российских дворян, и получить их неотколь...» [Волжские 2011: 260].

Попытка ставропольских зайсангов встать вровень с господствующим сословием российского общества успеха не имела: возможности обойти дворянскую монополию на «крещеную собственность», стать корпоративной «неодворянской» группой им не дали. Эволюция этого малого сообщества предполагала лишь один и вполне определенный путь - выход из этноязыко-

\section{Источники}

Волжские 2011 - Волжские ставропольские калмыки: середина 30-х гг. XVIII в. - первая половина XIX в. Документы и материалы. T. вой среды, культурное слияние с русским дворянством по примеру крещеных потомков хана Дондук-Омбо.

Впрочем, честолюбивым представителям данной страты вскоре представился и другой способ сломать социальный потолок - перейти к Е. И. Пугачеву. Хорошо известно о подобном выборе Ф. И. Дербетева, сына екатерининского депутата-законодателя. А. И. Шорин этого уже не увидел, ибо ставропольского «золотого века» не пережил: после 1768 г. он как толмач и учитель не упоминается, по всей вероятности, по причине ухода в мир иной.

\section{Заключение}

В изучаемое время важность посредничества «своих» калмыков в степных делах для государства была в целом велика. Однако в начале 1770-х гг. ситуация изменилась. Крушение Джунгарского ханства, надежность Оренбургской линии как пограничного рубежа, иные алгоритмы общения с тюрко-монгольской периферией России в совокупности означали, что крещеная калмыцкая верхушка стала не столь востребованной, а ее ценность в военно-политической системе пограничья снизилась.

С развитием екатерининской политики веротерпимости, лишавшей калмыковаристократов и их окружение в Ставрополе-на-Волге подпитки извне, они все более выступали реликтом сословной политики предшествующих эпох - ранней елизаветинской и даже бироновской. Отсутствие перспектив социального продвижения порождало нестабильность высшего командования Ставропольского войска, вызывало напряжение, желание порвать со сложившейся системой. Во время Пугачевщины они и дали себя знать. Результатом Пугачевщины для ставропольских «нобилей» стала их гибель, главенство в войске перешло к другим людям. Новое же поколение представляло собой заурядный командный состав иррегулярной части, лишенный социальных амбиций и способный держаться за корпоративные привилегии лишь в силу традиции.

1. Ставропольское калмыцкое войско в середине 30-х - 60-е гг. XVIII в. Ростов н/Д, $2011.320 \mathrm{c}$.

ПСЗ 1830 - Полное собрание законов Россий- 
ской империи: собрание первое: с 1649 по 12.12.1825. Т. 12 (1744-1748). СПб.: Тип. 2-го Отд-ния Собств. Е. И. В. Канцелярии, $1830.960 \mathrm{c}$.

\section{Sources}

Ryazhev A. S. (ed.) The Volga Stavropol Kalmyks: From the mid-1730s through the first half of the $19^{\text {th }}$ century. Documents and materials.

\section{Литература}

Абдилдабекова 2010 - Абдилдабекова A. M. Модели империй и их применимость к Казахстану в составе Российской Империи // Вестник Российского университета дружбы народов. Сер.: История России. 2010. № 1. C. $164-177$.

Арапов 2008 - Арапов Д. Ю. Ислам в архивных материалах высших государственных учреждений Российской империи (17211917 гг.) // Ab Imperio. 2008. № 4. C. 253-266.

Беликов 1971 - Беликов Т. И. Участие калмыков в Крестьянской войне под руководством Е. И. Пугачева (1773-1775 гг.). Элиста: Калмиздат, 1971. $167 \mathrm{c}$.

Беликов 1978 - Беликов Т. И. Ф. И. Дербетев сподвижник Е. И. Пугачева Элиста: Калм. кн. изд-во, 1978. 103 с.

Васильев 2017 - Васильев Д. В. Массовые народные движения как инструмент российской региональной политики в Казахской степи в конце XVIII в. (на примере движения Сырыма Датова) // Вестник Московского университета. Сер. 8: История. 2017. № 1. C. $31-43$.

Вовк, Шебалин 2016 - Вовк И. В., Шебалин И. А. «Присяга» и «подданство» в политической практике казахской элиты в 30-40-е гг. XVIII в. // Известия Волгоградского государственного педагогического университета. 2016. № 1 (105). С. 193-197.

Джунджузов 2013 - Джунджузов С. В. «Пугачевское замешательство» и Ставропольское калмыцкое войско // Вестник Самарского государственного университета. 2013. № 2 (103). С. 49-53.

Джунджузов 2020 - Джунджузов С. В. Правовое регулирование поселения калмыков в Оренбурге в 40-е годы XVIII века // Вестник Оренбургского государственного педагогического университета. 2020. № 1 (33). C. $80-89$.

Джунджузов, Любичанковский 2017 - Джунджузов С. В., Любичанковский С. В. Миссионерская деятельность Никодима Ленкееви-
Vol. 1. The Stavropol Kalmyk host from the mid-1730s through 1760s. Rostov-on-Don: Southern Scientific Center of the RAS, 2011. 320 p. (In Russ.)

First Complete Collection of Laws of the Russian Empire. St. Petersburg: Second Section of His Imperial Majesty's Own Chancery, 1830. Vol. 12: 1744-1748. 960 p.(In Russ.)

ча в Калмыцком ханстве (1725-1734 годы) // Новый исторический вестник. 2017. № 3 (53). С. 172-191.

Джунджузов, Любичанковский 2018 - Джунджузов С. В., Любичанковский С. В. Влияние имперской политики аккультурации на формирование и эволюцию властной элиты у ставропольских крещеных калмыков (1737-1842 гг.) // Былые годы. 2018. Т. 49. № 3. C. 970-979.

Дорджиева 2008 - Дорджиева Е. В. Конфессиональный вопрос в имперской политике по отношению к традиционной калмыцкой элите в XVIII веке // Известия Самарского научного центра РАН. 2008. Т. 10. № 4 (26). C. 975-982.

Ибнеева 2009 - Ибнеева Г. В. Имперская политика Екатерины II в зеркале венценосных путешествий. М.: Памятники исторической мысли, 2009. 467, [1] с.

Миллер 2006 - Миллер А. И. Империя Романовых и национализм: эссе по методологии исторического исследования. М.: НЛО, 2006. 248 c.

Петухов 2014 - Петухов А. В. Христианизация народов Среднего Поволжья в середине XVIII века в освещении современной американской историографии // Вестник Чувашского университета. 2014. № 4. С. 64-70.

Смирнов 2007 - Смирнов Ю. Н. Современные подходы к истории восстания 1773-1775 гг. // Вестник Самарского государственного университета. 2007. № 5/3 (55). С. 158-166.

Тебаев 2009 - Тебаев Д. Б. Проблема присоединения Степного края в XVIII-XIX вв. в современной российской историографии // Вестник Российского университета дружбы народов. Сер.: История России. 2009. № 5. С. 265-271.

Торопицын 2015 - Торопицын И. В. Астраханские юртовские татары в политико-административной системе взаимоотношений России с калмыками в XVII-XVIII вв. // Кочевые народы Центральной Евразии XVIIIXIX вв.: сравнительно-исторический анализ 
политики Российской империи. Алматы: Қазақ университеті, 2015. С. 155-179.

Третьякова, Мыслицкая 2015 - Третьякова Д. В., Мыслиикая Л. А. П. И. Рычков о волжских ставропольских калмыках: историко-ландшафтные и лингвогеографические наблюдения в «Топографии Оренбургской» // Вестник Волжского университета им. В. Н. Татищева. 2015. № 4 (19). С. 256-262.

Ходарковский 2019 - Ходарковский М. Степные рубежи России. Как создавалась колониальная империя. 1500-1800. М.: НЛО, 2019. 352 c.

Goryaev, Lidzhiev, Avliev 2019 - Goryaev M., Lidzhiev A., Avliev $V$. Christianization of Non-Russian Peoples: Missionary Activity of Orthodox Church in Kalmyk Plain // International Scientific Conference «Social and Cultural Transformations in the Context of Modern Globalism». The European Proceedings of Social \& Behavioural Sciences. 2019. Vol. LXXVI. 1136-1142.

\section{References}

Abdildabekova A. M. Models of empires and their applicability to Kazakhstan within the Russian Empire. RUDN Journal of Russian History. 2010. No. 1. Pp. 164-177. (In Russ.)

Arapov D. Yu. Supreme government agencies of the Russian Empire: Islam in archival materials (1721-1917). Ab Imperio. 2008. No. 4. Pp. 253-266. (In Russ.)

Belikov T. I. Fyodor Derbetev - a comrade-inarms of Yemelyan Pugachev. Elista: Kalmyk Book Publ., 1978. 103 p. (In Russ.)

Belikov T. I. Kalmyks in Pugachev's Rebellion: 1773-1775. Elista: Kalmizdat, 1971. 167 p. (In Russ.)

Dordzhieva E. V. The Russian Empire religious politics towards the Kalmyk traditional elite in the $18^{\text {th }}$ century. Izvestia of Samara Scientific Center of the RAS. 2008. Vol. 10. No. 4 (26). Pp. 975-982. (In Russ.)

Dzhundzhuzov S. V. 'Pugachev confusion' and Stavropol Kalmyk army. Vestnik of Samara University. 2013. No. 2 (103). Pp. 49-53. (In Russ.)

Dzhundzhuzov S. V. Legal regulation of the settlement of the Kalmyks in Orenburg in the 40 s of the XVIII century. Vestnik of Orenburg State Pedagogical University. 2020. No. 1 (33). Pp. 80-89. (In Russ.)
Frank 2001 - Frank, Allen J. Muslim Religious Institutions in Imperial Russia: The Islamic World of Novouzensk District and the Kazakh Inner Horde, 1780-1910. Leiden; Boston; Köln: E. J. Brill Academic Publishers, 2001. VIII, $341 \mathrm{p}$.

LeDonne 2008 - LeDonne J. P. Russia's eastern theater, 1650-1850 springboard or strategic backyard? // Cahiers du monde russe. 2008. Vol. 49. No. 1. Pp. 17-46.

Werth 2002 - Werth, Paul W. At the Margins of Orthodoxy. Mission, Governance and Confessional Politics in Russia's Volga Kama Region, 1827-1905. Ithaca; London: Cornell University Press, 2002. XIV, 269 p.

Werth 2013 - Werth, Paul W. The Qazaq Steppe and Islamic Administrative Exceptionalism: A Comparison with Buddhism Among Buriats // Islam, society and states across the Qazaq Steppe $\left(18^{\text {th }}-\right.$ early $20^{\text {th }}$ centuries $)$. Wien: Austrian Academy of Sciences Press, 2013. Pp. 119-142.

Dzhundzhuzov S. V., Lyubichankovskiy S. V. The influence of the imperial policy of acculturation on the formation and evolution of the power elite among the Stavropol Christened Kalmyks (1737-1842). Bylye Gody. 2018. Vol. 49. No. 3. Pp. 970-979. (In Russ.)

Dzhundzhuzov S. V., Lyubichankovsky S. V. The missionary activity of Nicodemus Lenkeevich in the Kalmyk Khanate (1725-1734). The New Historical Bulletin. 2017. No. 3 (53). Pp. 172191. (In Russ.)

Frank A. J. Muslim Religious Institutions in Imperial Russia: The Islamic World of Novouzensk District and the Kazakh Inner Horde, 1780-1910. Leiden; Boston; Koln: E. J. Brill Academic Publishers, 2001. VIII, 341 p. (In Eng.)

Goryaev M., Lidzhiev A., Avliev V. Christianization of non-Russian peoples: missionary activity of Orthodox Church in Kalmyk plain. In: International Scientific Conference 'Social and Cultural Transformations in the Context of Modern Globalism'. The European Proceedings of Social \& Behavioral Sciences. 2019. Vol. LXXVI. Pp. 1136-1142. (In Eng.)

Ibneeva G. V. Catherine the Great's Imperial Policies: in the Mirror of Her Majesty's Journeys. Moscow: Pamyatniki Istoricheskoy Mysli, 2009. 467 p. (In Russ.) 
Khodarkovsky M. Russia's Steppe Frontier: the Making of a Colonial Empire, 1500-1800. Moscow: Novoe Literaturnoe Obozrenie, 2019. 349 p. (In Russ.)

Le Donne J. Russia's eastern theater, 1650-1850 springboard or strategic backyard? Cahiers $d u$ monde russe. 2008. Vol. 49. No. 1. Pp. 17-46. (In Eng.)

Miller A. I. The Romanov Empire and Nationalism: an Essay on History Research Methodology. Moscow: Novoe Literaturnoe Obozrenie, 2006. 248 p. (In Russ.)

Petukhov A. V. Christianization of the Middle Volga peoples in the mid-eighteenth century in contemporary American historiography. Chuvash University Bulletin. 2014. No. 4. Pp. 64-70. (In Russ.)

Smirnov Yu. N. Modern approaches to the history of the rebellion 1773-1775. Vestnik of Samara State University. 2007. No. 5/3 (55). Pp. 158166. (In Russ.)

Tebaev D. B. Problem of connection of steppe edge in XVIII-XIX cen. In a modern Russian historiography. RUDN Journal of Russian History. 2009. No. 5. Pp. 265-271. (In Russ.)

Toropitsyn I. V. Russia and the Kalmyks, $17^{\text {th }}-18^{\text {th }}$ centuries: Yurt Tatars of Astrakhan Governorate in political and administrative perspectives. In: Central Asian Nomads, $18^{\text {th }}-19^{\text {th }}$ Centuries: a Comparative Historical Analysis of Russian Imperial Policies. Almaty: Al-Farabi Kazakh
National University, 2015. Pp. 155-179. (In Russ.)

Tretyakova D. V., Myslitskaya L. A. P. I. Rychkov about the Volga Stavropol Kalmyks: historicallandscape and linguogeographic notes of the book 'Topografiya Orenburgskaya'. Vestnik of Volzhsky University after V. N. Tatishchev. 2015. No. 4 (19). Pp. 256-262. (In Russ.)

Vasiliev D. V. Mass popular movements as an instrument of Russian regional policy in the Kazakh steppe in the late $18^{\text {th }}$ century (through the example of the Syrym Datov movement). Moscow University Bulletin. Series 8. History. 2017. No. 1. Pp. 31-43. (In Russ.)

Vovk I. V., Shebalin I. A. 'Oath' and 'citizenship' in the political practice of the Kazakh elite in the 30-40s of the XVIII century. Izvestia of the Volgograd State Pedagogical University. 2016. No. 1 (105). Pp. 193-197. (In Russ.)

Werth P. W. At the Margins of Orthodoxy. Mission, Governance and Confessional Politics in Russia's Volga - Kama Region, 1827-1905. Ithaca; London: Cornell University Press, 2002. XIV, 269 p. (In Eng.)

Werth P. W. The Qazaq Steppe and Islamic administrative exceptionalism: a comparison with Buddhism among Buriats. In: Islam, Society and States across the Qazaq Steppe (18 ${ }^{\text {th }}-$ Early 20 ${ }^{\text {th }}$ Centuries). Wien: Austrian Academy of Sciences Press, 2013. Pp. 119142. (In Russ.) 